\title{
Contrasting assigned expatriates and self- initiated expatriates: a review of extant research and a future research agenda
}

Book or Report Section

Accepted Version

Suutari, V., Brewster, C. and Dickman, M. (2018) Contrasting assigned expatriates and self-initiated expatriates: a review of extant research and a future research agenda. In: Dickman, M., Suutari, V. and Wurtz, O. (eds.) The management of global careers: exploring the rise of international work. Palgrave, London, pp. 63-89, Chapter 3. ISBN 9783319765280 Available at http://centaur.reading.ac.uk/71650/

It is advisable to refer to the publisher's version if you intend to cite from the work. See Guidance on citing.

Publisher: Palgrave

All outputs in CentAUR are protected by Intellectual Property Rights law, including copyright law. Copyright and IPR is retained by the creators or other 
copyright holders. Terms and conditions for use of this material are defined in the End User Agreement.

\section{www.reading.ac.uk/centaur}

\section{CentAUR}

Central Archive at the University of Reading

Reading's research outputs online 


\title{
CHAPTER 3
}

\author{
CONTRASTING ASSIGNED EXPATRIATES AND SELF-INITIATED \\ EXPATRIATES: A REVIEW OF EXTANT RESEARCH AND A FUTURE \\ RESEARCH AGENDA
}

\section{VESA SUUTARI, CHRIS BREWSTER, MICHAEL DICKMANN}

\section{EXPATRIATION IN HISTORICAL PERSPECTIVE}

The history of a concept has important implications for the way that knowledge is constructed and the assumptions that develop. Academic fields are built on the foundations of the strengths (and weaknesses) of the early pioneers and the trajectory of the field develops from those insights and those flaws, even if eventually it goes well beyond them. To advance we need, first, to acknowledge the base upon which our current understandings and knowledge have been built, then to fix any problems inherent in that base.

People have always moved around the Earth and expatriation (from the Latin ex-patria: out of country) has existed from the time when there were countries or other unified administered areas (such as city states, feudal regions) for people to expatriate from. Some of these journeys were to nearby territories but some involved journeys that, given the difficulties of travel in those days, can seem almost incredible: empires sent emissaries to far flung lands and religious history is full of stories of missionaries sent by the church to achieve their objectives amongst 'strangers' (Oberholster and Doss, 2016; Walker, Norris, Lotz and Handy, 1985). The Silk Road (or in fact roads) from China through many different countries to the edge of Europe dates back almost two millennia (Boulnois, 2004). The giant East India companies set up in 
the Netherlands and Britain to trade with the Far East were established well over four hundred years ago (Stening, 1994).

During these times, national boundaries were rather fungible. The formal introduction of passports as a requirement to cross borders was established during and after the First World War (Marrus, 1985). The term 'expatriate' was first used in the 17th century and for much of the time since then, it has had a very broad definition. An 'expatriate' is someone living outside their native country (Oxford Dictionary of English, 2015) or someone who has been sent or exiled abroad (Collins Dictionaries, 2011). According to Green (2009, p.308) it is a contradictory concept whereby, "The meaning of expatriation ... varies depending on who is initiating the act, the state or the individual, and whether or not it is voluntary. The state banishes; the subject can choose to depart."

For much of the last century 'expatriate' was typically used to describe Westerners who lived abroad for varying lengths of time (Cleveland, Mangone and Adams, 1960; Copeland and Griggs, 1985), including artists, writers, musicians, colonial administrators and those with some kind of mission such as teachers, NGO workers, students, interns, or volunteers: it was mainly used as a synonym for what are now commonly referred to as 'migrants'. If they were in employment, they received standard rates with little uplift for living abroad other than adjustments so that they were no worse off than if they had stayed at home (diplomats, United Nations workers, etc.) or they received local terms and conditions (Bickers, 2010; Cohen, 1977; Earnest, 1968). Recent attempts have been made to reintroduce this wider definition into the management literature (Al Ariss and Syed, 2011; Andresen, Bergdolt, Margenfeld and Dickmann, 2014; Dumont and Lemaitre, 2005). Using this approach it has been suggested that 
the number of expatriates is high, perhaps over 200 million (Clarke, Akhentoolove and Punnett, 2016).

The business literature began to recognise the importance of internationalization during the last century (Coase, 1937; Dunning, 1958; Kolde and Hill, 1967). Between 1970 and 2005, the number of multinational corporations (MNCs) grew from 7,000 to 70,000, with the same rate of growth expected to continue for the next 30 years (Salt, 2008). Almost inevitably, the literature gradually began to focus on people being moved abroad for (private, public or third sector) business reasons.

It was the 1950s before the early academic research into business expatriates began. As studies investigated American companies expanding abroad, there developed an associated literature exploring the challenges related to managing 'overseas executives' (Howell and Newman, 1959; Wallace, 1959). Around the 1960s the first studies examined these executives' intercultural experiences (Lysgaard, 1955; Oberg, 1960), relevant success factors (Kiernan, 1963), issues associated with how they transferred knowledge (Negandhi and Estafen, 1965), their careers (Gonzalez and Negandhi, 1967) and how they were selected (Borrmann, 1968; Triandis, 1963) and compensated (Schollhammer, 1969). There were also studies of expatriates in non-corporate settings, such as aid organizations (Taylor, 1968), the Peace Corps (Hapgood, 1968) and the military (Campbell, 1969).

The following decade saw articles examining why companies used expatriates (Baker and Ivancevich, 1971), their satisfaction (Ivancevich and Baker, 1970) and their communities (Cohen, 1977); and further work on their selection (Miller, 1973) and their compensation (Foote, 1977; Reynolds, 1972). There were the first studies of the expatriates themselves - their 
success and failure characteristics (Baker and Ivancevich, 1971; Lanier, 1979; Miller, 1972), their repatriation concerns (Gama and Pedersen, 1977; Heenan, 1970; Murray, 1973) and assignment outcomes (Miller, 1975; Misa and Fabricatore, 1979). Other work looked at their training needs (Jones, 1975) and at their decision making criteria when undertaking an international assignment (Mincer, 1978). There was the first article examining gender roles (Adler, 1979). Interest spread. There were articles reporting research into Japanese multinational enterprises or MNEs (Peterson and Schwind, 1977; Yoshino, 1976).

Expatriate researchers in the 1980s and 1990s followed these early beginnings, reporting on both the human resource management policies MNEs used in relation to their expatriates (Mendenhall, Dunbar and Oddou, 1987; Peterson, Sargent, Napier and Shim, 1996) and on the expatriates themselves (Black and Gregersen, 1991; Feldman and Thomas, 1992; Torbiorn, 1982; Tung, 1988).

All of these early papers took their data from the MNEs themselves and largely 'subcontracted' construct definition to the employers - if they were included under that heading in the employers' databases then they were assigned expatriates (AEs). The weaknesses of this approach became clear when Suutari and Brewster (2000), using comprehensive database not drawn from employers, identified different types of expatriates going abroad on their own initiative in different stages of their career and introduced the term self-initiated foreign expatriates (SIEs). The study thus expanded the work by Inkson, Arthur, Pringle and Barry, (1997) who analysed the experiences of 'young people heading overseas for a prolonged period of travel, work and tourism' to get overseas experience (called OE) which was a common phenomenon in New Zealand and Australia. Since then there has been a plethora of studies examining SIEs and a burst of activity attempting to identify 'new' categories of expatriate, 
often through the mechanism of re-naming existing categories (McNulty and Brewster, 2016). This creates a lack of construct clarity and a lack of construct validity and these are important if we are to advance understanding. Here, therefore, we adopt the definition of expatriates as: "legally working individuals who reside temporarily in a country of which they are not a citizen in order to accomplish a career-related goal, being relocated abroad either by an organization, by self-initiation or directly employed within the host-country" (McNulty and Brewster, 2016). It can be seen that we are linking our definition of expatriates to employment - if they are not working then these people are not subject to any form of international human resource management or careers and hence are outside our scope. Within this overall definition we separate out AEs, defined as those who meet the preceding definition but are sent to their new country by their employing organization - including those loaned to another employer by their own organization such as football players or experts going to regulatory bodies, usually with enhanced terms and conditions and the possibility to return to their home country in a position with the same organization after the assignment. In turn, SIEs, defined as those who secured their employment in a new country through their own initiative, are generally on standard or local employment conditions.

To explore these issues we adopt the following format for this chapter. We discuss first the motives of both AEs and SIEs for international work. Second, the nature of careers and jobs of AEs and SIEs are analysed. Third, we discuss the outcomes of expatriation for different types of expatriates. After that we will explore the management of such expatriates. Finally, we will draw some conclusions and discuss future research needs.

\section{Motives for International Work among AEs and SIEs}


Even in early expatriate studies that were focused on AEs (Miller and Cheng, 1978) it was reported that personal interest related to internationalism played an important role alongside financial benefits in the motives for moving abroad. Later studies identified the search for new challenges, possibilities for development and career progress as other important factors (Stahl, Miller and Tung, 2002; Bossard and Peterson 2005). Hippler (2009) concludes that four motives appear most consistently in the literature and in his own research: career prospects, development of job-related skills, financial benefits and internationalism. In a study of why AEs and SIEs move to London, Dickmann (2013) found six key categories that impact on the decision to work abroad. The key influences on the decision to go were career and development considerations, individual interests and drivers such as a desire for adventure, concerns about family and friends, the assessment of monetary and non-monetary organizational incentives, host country context (including nature, history, climate and security) and specific location considerations taking account of host in-country variations.

When discussing the motives of SIEs, it is important to note that SIEs form a very diverse group and thus motives vary (Suutari and Brewster, 2000). There have been some studies among students and young graduates with, the findings indicating that the major reasons for taking international jobs were excitement, cross-cultural experiences, growth, meeting new and different people and also future career prospects (Tharenou, 2003). Early international experiences through education increase the likelihood of seeking a job in the same location afterwards (Baruch, Budhwar and Khatri, 2007). Whilst companies rarely send inexperienced employees as AEs to international assignments, young people seem keen to go abroad on their own initiative as SIEs. Due to their early career stage, young people are also more commonly motivated by simply finding a job, especially when the home country job markets may offer 
fewer possibilities (Suutari and Brewster, 2000). They also reported professional development and career progress as more important motives than SIEs in general.

There have also been studies of the motives of SIEs working in specific sectors. For example, the internationalization of higher education has led to increasing interest amongst academic SIEs (Richardson and Mallon, 2005; Selmer and Lauring, 2010). These academics have been found to have three dominant motivations: adventure/travel, life change and family although financial reasons were significant in a number of cases (Richardson and Mallon, 2005). SIEs also often find work in the not-for-profit sector, where motivation is often values-based (Doherty et al., 2011) and includes dedication to a cause (Cerdin and Le Pargneux, 2010). The motives of SIEs working within international organizations such as the European Union and the United Nations have been found to differ to some extent from the average SIEs, since they regard economic benefits, personal interest toward internationalization and new experiences as slightly more important motives (Suutari and Brewster, 2000; Dickmann and Cerdin, 2016). Sometimes the motive of the SIEs is directly linked to their family situation through a dual career situation, i.e. SIEs have gone abroad due to the assignment of their spouse and then found a job for themselves in order to continue their own career. This is much easier in regions such as the European Union, where work permits are not necessary for member states citizens and active policies exist to encourage mobility (Doherty, Dickmann and Mills, 2010).

Oberholster, Clarke, Bendixen and Dastoor, (2013) have analysed the expatriate motivation in religious and humanitarian non-profit-organizations and found that altruism (consisting of opportunities to make a difference, a sense of calling to help others and the meaningfulness of the assignment) is the most important underlying reason for accepting work abroad. This was followed by an interest in international experiences and family reasons. According to Fee and 
Karsaklian (2013) international voluntary workers are increasingly also motivated by more self-directed and pragmatic outcomes such as adventure and excitement, or professional and personal development.

Overall, whilst the motives for international work are quite similar among AEs and SIEs, the different groups stress different aspects. For example, Doherty et al., (2011) found that career factors were seen as important by both AEs and SIEs while location and the host country reputation were particularly important for SIEs. Lifestyle is a very important career anchor for both AEs and SIEs but is more important for SIEs (Cerdin and Le Pargneux, 2010; Doherty et al., 2011). Overall, family related concerns play a central role among SIEs who have less company-related motives to take into account in their decision making (Richardson, 2006). At the same time, SIEs are likely to be less strongly motivated by the job than AEs though it is important for both groups (Cerdin, 2013). However, this finding does not apply to the humanitarian expatriates. Further, push factors such as a desire to escape the economic environment of their home country or to escape personal problems emerge more commonly among SIEs than AEs.

\section{The Nature of Careers and Jobs of AEs and SIEs}

Though both AEs and SIEs have international careers, the logic of such careers is to some extent different. As SIEs search their job abroad on their own, their assignment implies normally a movement between different organizations simultaneously with the move across national borders. AEs, by definition, move within the boundaries of one organization. Consequently, AEs regard their assignment as part of their organizational career, while SIEs tend to follow an individualized career path (Andresen, Al Ariss and Walther, 2013). AEs are thus mostly supported in their career moves by HRM professionals and the international 
assignment policies of the MNCs. SIEs not only look for their job on their own but also handle all the transfer complications themselves. Here again, the type of SIE matters - those going to work for international organizations will have support from the EU or the UN or whichever body they have got a job with. Other SIEs and often trailing partners find a job after their arrival in a new country (Peltokorpi, 2008), although they often also search for jobs abroad before they go. They may start with locations they find attractive or where they are familiar with the language or culture or that are closer to their home country and thus easier to move into than more distant and difficult locations (Suutari and Brewster, 2000). The number of AEs in turn is frequently reduced within MNCs in more developed societies and often also with the more established business operations of MNCs in these countries while new operations in more undeveloped locations or organizational business units require more extensive use of expatriates.

On average, SIEs often work in lower hierarchical positions in organizations (Jokinen, Brewster and Suutari, 2008; Doherty et al., 2011) and so may have less challenging tasks than AEs (Suutari and Brewster, 2000). However, the variation in the jobs held by SIEs is wide, due to the diversity of the SIE group. Because of a lack of social connections in the new country, job seeking may not be an easy task for self-initiated expatriates and thus SIEs are exposed to potential under-employment which may influence their motivation and career (Lee, 2005). It is also more common among AEs to work for big international MNCs than among SIEs (Jokinen, Brewster and Suutari, 2008).

It seems to be the case that there are more women amongst the SIE category than amongst AEs, and they are often younger and thus less likely to be moving with their family than typical AEs (Doherty et al., 2011). When companies send their employees abroad they are usually 
professionally more experienced, whilst among SIEs there are different kinds of people from very early career stages up to senior international professionals who have had long term international careers within many organizations (Suutari and Brewster 2000).

SIEs' tend to have longer international careers than AEs and o have a greater interest in considering more permanent global careers (Suutari and Brewster, 2000; Doherty et al., 2011). While MNCs typically limit the maximum lengths of international assignments (e.g. to three or five years after which the expatriate is encouraged to leave that country), SIEs often have no such time limitations in their local contracts. Due to their international orientation and sometimes also to limited possibilities after the assignment, the proportion of SIEs who have already worked abroad earlier tends to be higher than that of AEs (Jokinen, Brewster and Suutari, 2008). Similarly, in a longer-term follow-up study by Suutari, Brewster, Dickmann, Mäkelä and Tornikoski, (in press) it appeared that a significantly higher proportion of AEs than SIEs had repatriated back to their home country.

Repatriation agreements sometimes guarantee at least a similar level of job after the repatriation as before the assignment and AEs typically repatriate back to their home country in a similar or higher position within the same company. SIEs left their employer when moving abroad and thus usually have to find a new job in a new employer organization on return. It is therefore not surprising that SIEs, overall, intend to change organizations more than AEs (Biemann and Andresen, 2010). In that sense, in general, the careers of SIEs are more independent of organizational borders than those of AEs, although the evidence is that they do not fit easily into the predicted 'boundaryless' or 'protean' career mindsets (Suutari, Dickmann, Brewster and Mäkelä, 2016). If their jobs after the repatriation are not satisfying and the overall treatment of repatriation is not managed well, AEs too tend to start thinking about career options in 
external job markets. However, while there is evidence that the repatriate retention of AEs is lower than for their non-expatriated peers during the first year after return, the cumulative longterm retention effects seem to be similar (Doherty and Dickmann, 2012).

\section{What are the Outcomes of Expatriation for Different Types of Expatriates?}

One important question concerning expatriation in its different forms relates to the impacts of assignments on the individuals both in the short and longer term. This discussion links naturally with the previous discussion of the motives individuals have for moving abroad. It also raises organizational issues, i.e. what are the benefits of expatriation for the organizations in the longer run?

One of the main motives for expatriation was personal development and growth through facing new challenges. From this angle, the outcome appears to be positive. Various expatriate studies report extensive development taking place during assignments. This applies both to assigned and self-initiated expatriates (Dickmann et al., in press; Jokinen, Brewster and Suutari, 2008; Kraimer, Shaffer and Bolino, 2009; McNulty, 2013). The differences in starting point between assignees may impact to some extent on the development of AEs in comparison to SIEs. For example, given the stronger career and work-related motivation of AEs and their, on average, higher status and position, it is likely that AEs gain more organizational and business knowledge through their foreign work (Shaffer, Kraimer, Chen and Bolino, 2012). Because of their social connections within the MNC, AEs are also seen to be more likely to build better business contacts both at the head office and at their local operating unit (Farh, Bartol, Shapiro and Shin, 2010). In line with this reasoning, Dickmann et al., (in press) report that AEs developed more organizational knowledge and knowing whom career capital (i.e. relationships that can be beneficial to one's work and career) while working abroad than SIEs. However, in 
most areas, the extent of development was similar among both types of expatriates, indicating that all kinds of expatriates developed themselves while working abroad. Of course, all expatriates get international experience and develop related international competences. The level to which they are able to utilize such competences depends on their future careers, which we discuss next.

From the perspective of career progress the findings are quite mixed and the literature often suggests that the career impacts of international work are not as positive as AEs expect (Shaffer et al., 2012). It is quite common for AEs to leave their employer soon after repatriation (Kraimer, Shaffer, Harrison and Hong, 2012). However, some studies on career progression at high hierarchical levels indicate that international work experience has a positive impact on career success (Ng, Eby, Sorensen and Feldman, 2005; Magnusson and Boggs, 2006). Hamori and Koyuncu (2011) found that while the path to the top of the corporate ladder in large organizations may not be faster for executives who had international work experience, larger organizations often had former expatriates as CEOs. More research is needed to refine our picture of the career success of SIE and AE executives.

It is also important to note that as SIEs tend to stay longer abroad their social connections in the home country easily become weaker (Mäkelä and Suutari, 2013). This is often true in particular with regard to their organizational contacts, since as self-initiated expatriates they left their employer when moving abroad while most AEs still have connections back to their home country colleagues and the headquarters of the company (Dickmann and Doherty, 2010). On the other hand, it has also been reported that SIEs' international work experience increases both their chances of promotion with their current employer and their marketability in the external market (Richardson and Mallon, 2005). SIEs also tend to build stronger connections 
with locals and such connections may be used when seeking new jobs abroad. The latest evidence indicates that, among matched samples of highly educated business professionals, the career impacts of international assignments were found to be similar among SIEs and AEs (Suutari et al., in press). The only significant difference was that AEs got more jobs offers, and more often those were internal, than did SIEs, presumably as a consequence of their better networks within the organization that sent them abroad.

Over a longer term both AEs and SIEs saw their international marketability as having increased and being higher than their home country marketability, particularly so for SIE (Suutari et al., in press). If we combine this observation with the fact that high numbers of expatriates are interested in future international jobs, it is not surprising that a high proportion of both AEs and SIEs experience multiple foreign assignments (Stahl and Cerdin, 2004; Jokinen, Brewster and Suutari, 2008).

The financial impact of international assignments is naturally closely connected with the level of the position which the expatriate holds both abroad and after repatriation. Since AEs often work in higher organizational levels abroad and receive generous assignment packages that raise their standard of living and SIEs usually have local contracts with fewer benefits (Dickmann, 2016), the salary impacts differ between the groups. Positive salary impacts are found in some studies of AEs (Daily, Certo and Dalton, 2000; Carpenter, Sanders and Gregersen, 2001; Ramaswarmi, Carter and Dreher, 2016) but there is less information about SIEs. Clearly more evidence is needed both on the career progress and salary impacts of international experience. 
If we analyse the impacts of international assignments from the organizational perspective several observations can be made. First the overall development of expatriates abroad and their new international experience provide organizations with important talent that should be included in their talent management programmes (Cerdin and Brewster, 2014). There is an indication that global mobility professionals are aware of this and that some work actively to increase linkages of global mobility and talent management within organizations (Dickmann, 2015). International assignments are recognized as being among the best possible management development methods. In turn, the observation that many repatriates are unhappy with their treatment after the assignment and thus leave the organization or at least seriously consider doing so is a bad news. This raises the question of how SIEs and AEs are (and should be) managed by their employers.

\section{Management of International Assignees: AEs vs SIEs}

There is far more evidence on how AEs are being managed compared to SIEs (Doherty and Dickmann, 2013). Summaries of recommendations of how AEs are or should be managed, often linked to the expatriate cycle (Harris, Brewster and Sparrow, 2003), can be found in diverse publications (Dickmann, 2017; Dickmann and Baruch, 2011). Based on the discussion above, we are looking at the individual, organizational or wider contextual differences between the two types of international workers to explore the implications for the management of SIEs.

Targeting the Recruitment and Selection also to SIEs. It is clear that due to their home country insights and language skills, SIEs and AEs can be highly attractive employees for organizations, who can utilize them in jobs where these capabilities are useful. Since SIEs are more holistically oriented, putting less emphasis on career progression and professional development and more on individual factors such as adventure seeking or personal challenge 
(Cerdin, 2013; Doherty et al., 2011) means that employer branding and attraction strategies could stress different messages when aiming either at an (internal) audience of AEs or an external audience of SIEs or staff who may go on an international assignment in the future. Job aspects that show diverse situations or challenges could be emphasized by corporations. However, the scant evidence available shows that major German and French companies often do not mention global career opportunities on their websites (Point and Dickmann, 2012). In addition, SIEs are often seen to be highly educated and be more likely to be women compared to AEs. Given that they are financing and organizing their stay abroad themselves, it is argued that they are more interested in lower cost moves to secure environments (Andresen, Al Ariss and Walther, 2013; Dickmann and Cerdin, 2016) - with some exceptions in the not-for-profit sector. SIEs tend to have established a local network before they go abroad which may be used by organizations to attract foreign candidates to work for them. Overall, it is not only the attraction mechanisms but also the selection and job matching criteria that could factor in the different background, drivers and behaviours of SIEs.

Rethinking the Package Design of SIEs. The difference of monetary incentives and administrative support of AEs in comparison to SIEs is stark. First, AEs tend to earn substantially more than their peers on 'normal', local contracts. While contracts vary substantially, observers have consistently pointed out hefty expatriation premiums (Doherty and Dickmann, 2012; Dowling, Festing and Engle, 2013; Oltra, Bonache and Brewster, 2013). Some research points to a large variety of additional payments and support, including housing allowances, hardship payments, home leave flights and extra vacation days, family educational support, etc. (Dowling, Festing and Engle, 2013). Even the 'local plus' contracts where AEs who want to stay in their host country sign on to a local contract have certain perks included, most likely paid private schooling for expatriates' children (Dickmann, 2016). In turn, most 
SIEs sign a standard local contract and thus their contract does not include such extra benefits. Given the potentially highly useful SIE competencies - beyond language capabilities they have an in-depth understanding of their home culture, institutions, legal frameworks and have country-of-origin social networks - employers may consider giving them extra incentives to stay in the organization or to refresh their contacts and insights. This could include sponsored home trips or considerations to compensate some of the social security differences from which SIEs may suffer. This could increase the engagement levels of SIEs. Alternatively, companies could develop a more flexible system of where people live and work.

Strengthening the Current Cross-Cultural Training and Adjustment Support for SIEs. While even AEs often do not get much pre-departure training (Harris, Brewster and Sparrow, 2003; Doherty and Dickmann, 2012) and little cross-cultural adjustment support, SIEs are highly unlikely to get in-country cultural training (Haslberger and Vaiman, 2013). While some of the drivers of SIEs are closely connected to learning about and exploring their host country, and due to the fact that they seem to have a larger non-company host social network, it might be concluded that less adjustment support is needed for SIEs than AEs. Also, SIEs stay longer in the host country (Mäkelä and Suutari, 2013) and have more time to adjust. Nevertheless, offering some cultural training and local mentor/coaching networks may help SIEs especially during their initial time in country. Cultural understanding, especially the cognitive and behavioral components of adjustment (Haslberger, Brewster and Hippler, 2013), may be supported through such initiatives.

Tailoring HR Policies and Practices to Distinguish between AEs and SIEs. There are many HRM activities that affect AEs and SIEs. In relation to training and development, SIEs tend to be new to the organization and are likely to benefit more than AEs from host organization 
induction sessions and support for international in-company networking. In addition, SIEs are more likely to be female so that activities that support women in management (and other areas of activities) such as the work associated with the Female FTSE 100 (Vinnicombe, Doldor, Sealy, Pryce and Turner, 2015) may have positive effects. In addition, we have seen above that SIEs more often are on lower hierarchical levels which has an impact on the sorts of capabilities associated with in-job success. Sensitive and responsive training and development offers increase the chances of increased performance. Given that SIEs are highly self-driven individuals and are, on average, guided by a set of more holistic drivers - including a higher interest to interact with locals and to experience wide facets of the host environment - there are implications for work content, jobs assignments and for how to manage SIEs (Doherty and Dickmann, 2012; 2013). Interaction with host country nationals and local content of work that leads to learning are likely to be highly valued by SIEs.

Developing Organizational Repatriation Approaches for SIEs. SIEs are a population of workers who have a range of cross-cultural insights and skills by the time they return home. A stream of research has shown that they, like AEs, have benefitted tremendously from their international sojourn in terms of enduring career capital development and high external marketability (Suutari et al., in press; Dickmann et al., in press). It seems likely that MNCs would be well advised to work towards retaining SIEs who want to leave their host country, provided that the organization has sizeable operations in the country that they are moving to. One of the ways this could be done is simply to support their move financially. However, the issue is actually much broader. If organizations started to treat SIEs (once they are their employees) similar to AEs in terms of tailored career support and position finding then they are much more likely to find vacancies and home country opportunities. In addition, they may provide some of the reintegration support that may be even more needed by SIEs who, on 
average, stay much longer abroad. Overall, this would increase the chances of SIEs staying with their organization and in some sense becoming AEs on their way home. While this clearly happens informally in some cases, large MNCs may be well advised to develop more equitable policy approaches.

This section has argued that SIEs have the potential to be highly valuable to organizations at a price, i.e. their package while working abroad, that is substantially lower than that of AEs (Dowling et al., 2013. We have suggested, to start with, the differences that distinguish SIEs from AEs to develop HRM policies and practices in terms of recruitment and selection, training and development, career and performance management as well as repatriation approaches that are sensitive to their unique backgrounds, interests and demographics, in order to attract, develop, utilize and retain SIEs better.

\section{Conclusions and Recommendations for Future Work}

In this chapter we have systematically contrasted the similarities and differences in the motivations to work abroad, the nature of careers and jobs, outcomes of working abroad and the management of AEs and SIEs. After approximately half a century of expatriate research there is already much known in relation to 'traditional expatriation', even though the field is prone to changes and authors are finding new perspectives and new sub-groups. Systematic exploration of the SIE phenomenon, initiated more than one and a half decades ago, while beyond its infancy, still harbors many opportunities for exciting insights.

Amongst these opportunities are the fields that this chapter has chartered. For instance, with respect to the drivers of international work we have yet to explore why and how motivations change over time. Of course, there are many angles that could be investigated within the 
motivational arena such as the impact of life and career stages on individuals, gender and other diversity patterns, host country characteristics, etc. Within the psychological and sociological perspectives, broad well-being issues may be investigated. For instance, SIEs have to cope with a lot of insecurity and uncertainty (Richardson, 2006). Understanding their coping strategies and the effect of SIE work on well-being would be important. In addition, the findings on underemployment of SIEs and migrants may be further explored and links to job satisfaction, attachment to their host country and employer, intention to return or even happiness may be investigated.

The second large section of this chapter looked at the careers and jobs of international workers. There is some work using the intelligent career framework (DeFillippi and Arthur, 1994). The intelligent career is a modern career concept that explores three ways of knowing. Knowing how is the skills, knowledge and abilities that help individuals in their careers. Knowing whom is the reputation of individuals in the minds of others and their social contacts and networks that can further their careers. Knowing why consists of the motivations and drivers of individuals that give them energy to pursue a career journey and to succeed in the world of work. Individual careerists are advised to invest in these three ways of knowing (Inkson and Arthur, 2001). .With reference to global careers some emerging long-term studies show positive impacts for both AEs and SIEs (Suutari et al., in press; Dickmann et al., in press). Going beyond quantitative studies, tracing the development, transfer and utilization of career capital in different contexts and understanding the various influencing factors in-depth (for instance through qualitative studies) over time is still underexplored.

Our third section looked at outcomes of global work. Especially in relation to SIEs, the picture is still highly fragmented and partial. Often, SIEs have been treated predominantly as a 
'homogenous entity'. Understanding the impact of differences - educational, age, gender, nationality, hierarchical - would be highly important to be able to improve the exploration of influences on outcomes and sub-group patterns.

The fourth section of this chapter discussed the management of global workers. While we have some insights (albeit not perfect) in relation to AEs, the evidence of how SIEs are managed is sparse. Many of the suggestions we developed on how to manage SIEs better are logical inferences and high quality investigations are needed. These could, for instance, take an action research approach in which researchers cooperate with MNCs to put tailored SIE approaches in relation to their sourcing, management, development, careers and retention into practice. In addition, better information regarding the monetary and non-monetary packages of SIEs over time would be highly welcome. Moreover, the organizational context - industry, size of firm, host team, hierarchy of job, transnationality, etc. - will be important to factor into the research to better understand links.

Above, we have argued that an in-depth understanding of differences in SIE (and AE) subgroups would be highly beneficial (Dorsch, Suutari and Brewster, 2013). The nearer researchers get to a more holistic picture the better this is likely to be. Understanding location characteristics and their impact on SIEs and AEs (Dickmann, 2013; Doherty, Dickmann and Mills, 2010) is another piece of the puzzle. The impact of host country characteristics such as security, location, tolerance and acceptance of the host country population are likely to shape many outcomes of global mobility. We are all persuaded that improving our insights into global mobility remains a worthy and exciting aim. 


\section{References}

Adler, N. (1979). Women as adrogynous managers: A conceptualization of the potential for American women in international management. International Journal of Intercultural Relations, 3(4), 407-436.

Al Ariss, A. and Syed, J. (2011). Capital mobilization of skilled migrants: A relational perspective. British Journal of Management, 22(2), 286-304.

Andresen, M., Al Ariss A. and M. Walther. (2013) (Eds). Self-Initiated Expatriation. Individual, Organizational, and National Perspectives. London: Routledge.

Andresen, M., Bergdolt, F., Margenfeld, J. and Dickmann M. (2014), Addressing international mobility confusion - developing definitions and differentiations for self-initiated and assigned expatriates as well as migrants, International Journal of Human Resource Management, 25(16), 2295-2318.

Baker, J. and Ivancevich, J. (1971). The assignment of American executives abroad: Systematic, haphazard, or chaotic? California Management Review, 13(3), 39-44.

Baruch, Y., Budhwar, P.S. and Khatri, N. (2007). Brain drain: Inclination to stay abroad after studies. Journal of World Business, 42: 99 - 112.

Bickers, R. (2010). Settlers and expatriates: Britons over the seas. Oxford: Oxford University Press.

Biemann, T. and Andresen, M. (2010). Self-initiated foreign expatriates versus assigned expatriates. Two distinct types of international careers? Journal of Managerial Psychology, 25: $430-448$.

Black, J., and Gregersen, H. (1991). The other half of the picture: Antecedents of spouse crosscultural adjustment. Journal of International Business Studies, 22(3), 461-477.

Borrmann, W. (1968). The problem of expatriate personnel and their selection in international enterprises. Management International Review, 8(4/5), 37-48. 
Bossard, A.B. and Peterson, R.B. (2005) 'The repatriate experience as seen by American expatriates', Journal of World Business, 40(1): 9-28.

Boulnois, L. (2004). Silk Road: Monks, Warriors and Merchants on the Silk Road. Hong Kong: Odyssey Publications.

Campbell, R. (1969). United States military training for cross-cultural interaction. Office of Naval Research, June.

Carpenter, M., Sanders, G. and Gregersen, H. (2001). Bundling human capital with organizational context: the impact of international assignment experience on multinational firm performance and CEO pay, Academy of Management Journal, 44:3, 493-511.

Cerdin, J.-L. (2013). Motivation of self-initiated expatriates. In M. Andresen, A. Al Ariss, M. Walther and K. Wolff (Eds.), Self-initiated expatriation: mastering the dynamics (pp. 5974). London: Routledge.

Cerdin, J.-L. and Brewster, C. (2014). Talent Management and Expatriation: Bridging two streams of research and practice Journal of World Business, 49(2), 245-252.

Cerdin, J.L. and Le Pargneux, M. (2010). Career anchors: A comparison between organizationassigned and self-initiated expatriates. Thunderbird International Business Review, 52: 287 $-299$.

Clarke, L., Akhentoolove, C. and Punnett, B.-J. (2016). Expatriates to and from developed and developing countries. In Y. McNulty and J. Selmer (Eds.), The Research Handbook of Expatriates (pp. Forthcoming). London: Edward Elgar.

Cleveland, H., Mangone, G., and Adams, J. (1960). The Overseas Americans. New York, NY: McGraw-Hill.

Coase, R. (1937). The nature of the firm. Economica, 4(16), 386-405.

Cohen, E. (1977). Expatriate communities. Current Sociology, 24(23), 5-133.

Collins Dictionaries. (2011). Collins English Dictionary. Glasgow, UK: Collins. 
Copeland, L., and Griggs, L. (1985). Going international: How to make friends and deal effectively in the global marketplace. New York: Random House.

Daily, C.M., Certo, S.T. and Dalton, D.R. (2000). International experience in the executive suite: the path to prosperity, Strategic Management Journal, 21:4, 515-523.

DeFillippi, R. J., and Arthur, M. B. (1994). The boundaryless career: A competency-based perspective. Journal of Organizational Behavior, 15(4), 307-324.

Dickmann, M. (2013). Why do they come to London? Exploring the Motivations of Expatriates to Work in the British Capital, Journal of Management Development, Vol 31(8): 783-800.

Dickmann, M. (2015). The RES Forum Annual Report: Global Mobility and the Global Talent Management Conundrum, RES Forum, UniGroup Relocation Network and Equus Software, 108 pages, London.

Dickmann, M. (2016). The RES Forum Annual Report 2016: Beyond Uniformity - A World of Opportunity. RES Forum, Harmony Relocation Network and Equus Software, 116 pages, London.

Dickmann, M. (2017). International Human Resource Management, in T. Redman and A. Wilkinson Contemporary Human Resource Management, pp. 258-292, $5^{\text {th }}$ Edition, London: Prentice Hall.

Dickmann, M. and Baruch, Y. (2011). Global Careers, London: Routledge.

Dickmann, M. and Cerdin, J.-L. (2016). Exploring the Development and Transfer of Career Capital in an International Governmental Organization, The International Journal of Human Resource Management, published online 5. Oct.

Dickmann, M. and Doherty, N. (2010). "Exploring Organisational and Individual Career Goals, Interactions and Outcomes of International Assignments", Thunderbird International Review, Vol 52 (4): 313-324. 
Dickmann, M., Suutari, V., Brewster, C., Mäkelä, L., Tanskanen, J. and C. Tornikoski (in press). The Career Competencies of Self-Initiated and Assigned Expatriates: Assessing the Development of Career Capital over Time. The International Journal of Human Resource Management. published online 04. May

Doherty, N. and Dickmann, M. (2012). Measuring the return on investment in international assignments: an action research approach. International Journal of Human Resource Management, Vol 23(16): 3434-3454.

Doherty, N. and Dickmann, M. (2013). Self-initiated expatriation: Drivers, employment experience and career outcomes. In M. Andresen, A. Al Ariss, M. Walther, and K. Wolff (Eds.), Self-initiated expatriation: mastering the dynamics (pp. 122-142). London: Routledge.

Doherty, N., Dickmann, M. and Mills, T. (2010) Mobility attitudes and behaviours among young Europeans, Career Development International, Vol 15 (4): 378-400.

Doherty, N., Dickmann, M. and Mills, T. (2011). "Exploring the Motives of CompanyBacked and Self-Initiated Expatriates", The International Journal of Human Resource Management, Vol 22(3): 595-611.

Dorsch, M., Suutari, V. and C. Brewster. (2013), Research on Self-Initiated Expatriation: History and Future Directions. In Andresen, M., Al Ariss A., and M. Walther. (Eds). SelfInitiated Expatriation. Individual, Organizational, and National Perspectives. London: Routledge.

Dowling, PJ, Festing, M., and Engle, A. (2013). International human resource management (6th ed.), London: Cengage Learning.

Dumont, J. and Lemaitre, G. (2005). Counting Immigrants and Expatriates in OECD Countries: A new perspective. Retrieved from New York, NY: UN LIbrary 
Dunning, J. (1958). American investment in British manufacturing industry. London: George Allen and Unwin.

Earnest, E. (1968). Expatriates and patriots: American artists, scholars and writers in Europe. Durham, NC: Duke University Press.

Farh, C. I. C., Bartol, K. M., Shapiro, D. L. and Shin, J. (2010). Networking abroad: A process model of how expatriates form support ties to facilitate adjustment. Academy of Management Review, 35(3), 434-454.

Fee, A. and E. Karsaklian. (2013). Could international Internatonal volunteers be considered ethical consumers? A cross-discipline approach to understanding motives of self-initiated expatriates. In Vaiman V. and Haslberger A. (eds), Talent Management of Self-initiated Expatriates: A Neglected Source of the Global Talent Flow. Palgrave Macmillan.

Feldman, D. C. and Thomas, D. C. (1992). Career management issues facing expatriates. Journal of International Business Studies, 23(2), 271-293.

Foote, M. R. (1977). Controlling the cost of international compensation. Harvard Business Review, 55(6), 123-132.

Gama, E. and Pedersen, P. (1977). Readjustment problems of Brazilian returnees from graduate studies in the United States. International Journal of Intercultural Relations, 1(4), 46-59.

Gonzalez, R. and Negandhi, A. (1967). The United States overseas executive: his orientations and career patterns. East Lansing, MI: Michigan State University.

Green, N. (2009). Expatriation, expatriates, and expats: The American transformation of a concept. American Historial Review, 114(2), 307-319.

Hamori, M. and Koyuncu, B. (2011). 'Career advancement in large organizations in Europe and the United States: do international assignments add value', International Journal of Human Resource Management, 22:4, 843-862. 
Hapgood, D. (1968). Agents of change: A close look at the peace corps. Boston, MA: Little, Brown and Co.

Harris, H., Brewster, C. and Sparrow, P. (2003). International human resource management. CIPD Publishing.

Haslberger, A., Brewster, C. and Hippler, T. (2013). The dimensions of expatriate adjustment. Human Resource Management, 52(3), 333-352.

Haslberger, A. and Vaiman, V. (2013). Self-initiated expatriates: A neglected source of the global talent flow. In Talent Management of Self-Initiated Expatriates (pp. 1-15). Palgrave Macmillan UK.

Heenan, D. (1970). The corporate expatriate: Assignment to ambiguity. Columbia Journal of World Business, 5(3), 49-54.

Hippler, T. (2009). Why do they go? Empirical evidence of employees' motives for seeking or accepting relocation. International Journal of Human Resource Management, 20:6, 13811401.

Howell, M., and Newman, S. (1959). How we should train for overseas posts. The International Executive, 1(1), 21-22.

Inkson, K., and Arthur, M. B. (2001). How to be a successful career capitalist. Organizational Dynamics, 30(1), 48-61.

Inkson, K., Arthur, M.B., Pringle, J. and Barry, S. (1997) Expatriate assignment versus overseas experience: contrasting models of international human resource development, Journal of World Business, 32 (4): 351-368.

Ivancevich, J., and Baker, J. (1970). A comparative study of the satisfaction of domestic United States managers and overseas United States managers. Academy of Management Journal, 13(1), 69-77. 
Jokinen, T., Brewster, C. and Suutari, V. (2008). Career capital during international work experiences: contrasting self-initiated expatriate experiences and assignees expatriation. International Journal of Human Resource Management, 19(6), 979-998.

Jones, L. (1975). Training in the jungle - CALTEX style. Education + Training, 17(1/2), 4548.

Kiernan, P. (1963). What it takes to be a successful international manager. The International Executive, Fall(3).

Kolde, E., and Hill, R. (1967). Conceptual and normative aspects of international managment. Academy of Management Journal, 10(2), 119-128.

Kraimer, M., Shaffer, M. and Bolino, M. (2009). The influence of expatriate and repatriate experiences on career advancement and repatriate retention. Human Resource Management, 48(1), 27-48.

Kraimer, M. L., Shaffer, M. A., Harrison, D. A. and Hong, R. (2012). No place like home? An identity strain perspective on repatriate turnover. Academy of Management Journal, 55(2), $399-420$.

Lanier, A. R. (1979). Selecting and preparing personnel for overseas transfers. Personnel Journal, 58(3), 160-163.

Lee, C. H. (2005). A study of underemployment among self-initiated expatriates. Journal of World Business, 40(2), 172-187.

Lysgaard, S. (1955). Adjustment in a foreign country: Norwegian Fulbright grantees visiting the United States. International Social Sciences Bulletin, 7, 45-51.

Magnusson, P. and Boggs, D.J. (2006). International experience and CEO selection: an empirical study, Journal of International Management, 12:1, 107-125. 
Mäkelä, K. and Suutari, V. (2013). Social Capital of Traditional and Self-Initiated Expatriates. In: Vaiman V. and Haslberger A. (eds), Talent Management of Self-initiated Expatriates: A Neglected Source of the Global Talent Flow. Basingstoke: Palgrave Macmillan.

Marrus, M. (1985). The unwanted: European refugees in the twentieth century. New York, NY: Oxford University Press.

McNulty, Y. (2013). Are self-initiated expatriates born or made? Exploring the relationship between SE orientation and individual ROI. In V. Vaiman, and A. Haslberger (Eds.), Talent Management of Self-Initiated Expatriates: A Neglected Source of Global Talent (pp. 30 58). New York: Palgrave Macmillan.

McNulty, Y. and Brewster, C. (2016). Theorising the meaning(s) of expatriate: establishing boundary conditions. International Journal of Human Resource Management.

Mendenhall, M., Dunbar, E. and Oddou, G. (1987). Expatriate selection, training and careerpathing: A review and critique. Human Resource Management, 26(3), 331-345.

Miller, E. (1972). The selection decision for an international assignment: A study of the decision maker's behavior. Journal of International Business Studies, 3(2), 49-65.

Miller, E. (1973). The international selection decision: A study of some dimensions of managerial behavior in the selection decision process. Academy of Management Journal, $16(2), 239-252$.

Miller, E. (1975). The job satisfaction of expatriate American managers: A function of regional location and previous international work experience. Journal of International Business Studies, 6(2), 65-73.

Miller, E. and Cheng, J. (1978). A closer look at the decision to accept an overseas position. Management International Review, 18(3), 25-33.

Mincer, J. (1978). Family migration decisions. Journal of Political Economy, 86(5), 749-773 
Misa, K., and Fabricatore, J. (1979). Return on investment of overseas personnel. Financial Executive, 47, 42-46.

Murray, J. (1973). International personnel repatriation: Culture shock in reverse. MSU Business Topics, 21(3), 59-66.

Negandhi, A. and Estafen, B. (1965). A research model to determine the applicability of American management know-how in differing cultures and/or environments. Academy of Management Journal, 8(4), 309-318.

Ng, T.W.H., Eby, L.T., Sorensen, K.L. and Feldman, D.C. (2005). 'Predictors of objective and subjective career success: a meta-analysis', Personnel Psychology, 58:2, 367-408.

Oberg, K. (1960). Cultural shock: Adjustment to new cultural environments. Practical Anthropology, 7(4), 177-182.

Oberholster, A.J., Clarke, R., Bendixen, M. and B. Dastoor (2013). Expatriate motivation in religious and humanitarian non-profit-organizations. Journal of Global Mobility, 1:1, 7-27.

Oberholster, B. and Doss, C. (2016). Missionary (religious) expatriates. In Y. McNulty and J. Selmer (Eds.), The Research Handbook of Expatriates (pp. FORTHCOMING). Cheltenham, UK: Edward Elgar.

Oltra. V., Bonache, J.and Brewster, C. (2013) A new framework for understanding inequalities between expatriates and host country nationals Journal of Business Ethics, 115 (2) $291-310$

Oxford Dictionary of English. (2015). (3rd ed.): Oxford University Press.

Peltokorpi, V. (2008). Cross-cultural adjustment of expatriates in Japan. International Journal of Human Resource Management, 19(9), 1588-1606.

Peterson, R., Sargent, J., Napier, N. and Shim, W. (1996). Corporate expatriate HRM policies, internationalisation, and performance in the world's largest MNCs. Management International Review, 36(3), 215-230. 
Peterson, R. and Schwind, H. (1977). A comparative study of personnel problems in international companies and joint ventures in Japan. Journal of International Business Studies, 8(1), 45-56.

Point, S., and Dickmann, M. (2012). Branding international careers: An analysis of multinational corporations' official wording. European Management Journal, 30(1), 18-31.

Ramaswarmi, A., Carter, N. M. and Dreher, G. F. (2016 forthcoming). Expatriation and career success: A human capital perspective. Human Relations.

Reynolds, C. (1972). Career paths and compensation in MNCs. Columbia Journal of World Business, 7(6), 77-87.

Richardson, J. (2006). Self-directed expatriation: Family matters. Personnel Review, 35(4), $469-486$.

Richardson, J. and Mallon, M. (2005). Career interrupted? The case of the self-directed expatriate. Journal of World Business, 40: 409 - 420.

Salt, B. (2008). The global skills convergence: Issues and ideas for the management of an international workforce. Switzerland: KPMG.

Schollhammer, H. (1969). Compensation of international executives. Michigan State University Business Topics, 17(1), 19-30.

Selmer, J. and Lauring, J. (2010). Self-initiated academic expatriates: Inherent demographics and reasons to expatriate. European Management Review 7(3): 169-179.

Shaffer, M. A., Kraimer, M. L., Chen, Y. P. and Bolino, M. C. (2012). Choices, challenges, and career consequences of global work experiences: A review and future agenda. Journal of Management, 37(4), 1282-1327.

Stahl, G. and Cerdin, J-L. (2004). 'Global careers in French and German multinational corporations', Journal of Management Development, 23:9, 885-902. 
Stahl, G.K., Miller, E.L. and Tung, R.L. (2002). Toward the boundaryless career: a closer look at the expatriate career concept and the perceived implications of an international assignment, Journal of World Business, 37(3): 216-227.

Stening, B. (1994). Expatriate management: Lessons from the British in India. The International Journal of Human Resource Management, 5(2), 385-404.

Suutari, V. and Brewster, C. (2000). Making their own way: International experience through self-initiated assignments. Journal of World Business, 35(4), 417-436.

Suutari, V., Brewster, C., Dickmann, M., Mäkelä, L. and C. Tornikoski (in press). The effect of international work experience on the career success of expatriates: a comparison of assigned and self-initiated expatriates. Human Resource Management.

Suutari, V., Dickmann, M., Brewster, C. and Mäkela, L. (2016). Expatriation and the Boundaryless Career - Empirical Evidence. European Academy of Management Conference, Manageable Cooperation? June 1 - 4, Paris, France.

Taylor, A. (1968). The selection of N.Z. volunteers for service abroad: an appraisal of the first five years. Personnel Psychology, 21(3), 345-357.

Tharenou, P. (2003). The initial development of receptivity to working abroad: Self-initiated international work opportunities in young graduate employees. Journal of Occupational and Organizational Psychology, 76: 489 - 515.

Torbiorn, I. (1982). Living abroad: Personal adjustment and personnel policy in the overseas setting. New York, NY: Wiley.

Triandis, H. (1963). Factors affecting employee selection in two cultures. Journal of Applied Psychology, 47(2), 89-96.

Tung, R. (1988). Career issues in international assignments. Academy of Management Executive, 11(3), 241-244. 
Vinnicombe, S., Doldor, E., Sealy, R., Pryce, P., and Turner, C. (2015). The Female FTSE Board Report 2015.

Walker, W., Norris, R. A., Lotz, D. W., and Handy, R. T. (1985). A history of the christian church (4th Ed.). New York, NY: Scribner.

Wallace, W. (1959). How to maintain productive working relationships with overseas managers. The International Executive, 1(2), 17-18.

Yoshino, M. (1976).Japan's multinational enterprises. Cambridge, MA: Harvard University Press. 